\title{
Targeting constitutive NF-кB specifically in tumor cells
}

\section{Ji-Hak Jeong, Shohreh Iravani Dickinson and Jun-Li Luo}

$\mathrm{NF}-\kappa \mathrm{B}$ transcription factors are the key regulators of innate and adaptive immune responses, inflammation, and cell survival [1]. Considerable evidences indicate that $\mathrm{NF}-\kappa \mathrm{B}$ plays important roles in carcinogenesis, cancer progression, metastasis and drug resistance, and therefore $\mathrm{NF}-\kappa \mathrm{B}$ has been regarded as one of the most important targets for cancer therapy [2]. However, the application of inhibitors that target $\mathrm{NF}-\kappa \mathrm{B}$ or $\mathrm{NF}-\kappa \mathrm{B}$ pathways for the treatment of human cancer is impeded by severe side effects due to the indiscriminate inhibition of NF- $\mathrm{KB}$ in normal immune cells.

Traditionally, there are two $\mathrm{NF}-\kappa \mathrm{B}$ activation pathways that play important roles in immune responses. The first pathway, also called canonical or classical NF- $\kappa$ B activation pathway, is triggered in response to microbial and viral infections and exposure to proinflammatory cytokines that induce activation of the tripartite IKK complex and the consequent phosphorylation-related degradation of $\mathrm{I} \kappa \mathrm{Bs}$, leading to the nuclear translocation of NF-кB complexes, predominantly p50/RelA and p50/c-Rel dimmers [3]. The second pathway, also called non-canonical or alternative NF- $\kappa \mathrm{B}$ activation pathway, involves different signaling molecules and leads to the predominant activation of $\mathrm{p} 52$ :RelB NF- $\kappa \mathrm{B}$ dimers by inducing processing NF- $\kappa \mathrm{B} 2 / \mathrm{p} 100$ precursor that binds to the RelB NF- $\kappa$ B subunit in the cytoplasm [4].

As more and more reports suggest that NF- $\kappa B$ is activated in most cancer cell lines and tumor cells, especially in those tumor cells that resist to chemo- or/ and radiotherapy, it becomes a consensus for the research community that $\mathrm{NF}-\kappa \mathrm{B}$ plays a major role in tumor development and cancer therapy-resistance. However, we seemed ignore the differences between NF- $\kappa \mathrm{B}$ (acute) activation in immune responses and $\mathrm{NF}-\kappa \mathrm{B}$ constitutive activation in tumor cells, and also ignore or sometimes confuse the differences between the activation of NF$\kappa \mathrm{B}$ pathways and the activation of $\mathrm{NF}-\kappa \mathrm{B}$ itself. In fact, as demonstrated in both transgenic/knockout and allograft/xenograf mouse models in our studies $[5,6]$, the constitutive activation of NF- $\mathrm{NB}$ in tumor cells is different from NF- $\mathrm{BB}$ (acute) activation in immune cells, and the constitutive activation of NF- $\kappa \mathrm{B}$ in tumor cells doesn't dependent on traditional NF- $\kappa \mathrm{B}$ pathways, which are normally related to the activation of IKK $\beta$ or IKK complex [5]. This can explain why the IKK $\beta / \mathrm{IKK}$ inhibitors are not as powerful for the inhibition of tumor cell proliferation and tumor growth as expected or as what theoretically they should do.
Importantly, our studies have shown that it is the constitutive $\mathrm{NF}-\kappa \mathrm{B}$ activation that drives tumor prostate cancer recurrence and therapy-resistance. And the constitutive NF- $\kappa \mathrm{B}$ activation is established and maintained by a feed-forward signaling circuit composed of $\mathrm{I} \kappa \mathrm{B} \alpha / \mathrm{NF}-\kappa \mathrm{B}(\mathrm{p} 65)$, miR-196b-3p, Meis2, PPP3CC, where the constitutive $\mathrm{I} \kappa \mathrm{B} \alpha / \mathrm{NF}-\kappa \mathrm{B}(\mathrm{p} 65)$ drives the expression of miR-196b-3p that inhibits the expression of Meis2 and PPP3CC, down-regulated PPP3CC is unable to dephosphorylates $\mathrm{p}-\mathrm{I} \kappa \mathrm{B} \alpha$, leading to constitutive $\mathrm{I} \kappa \mathrm{B} \alpha$ phosphorylation and $\mathrm{NF}-\kappa \mathrm{B}(\mathrm{p} 65)$ activation (Figure 1). Therefore, targeting this constitutive $\mathrm{NF}-\kappa \mathrm{B}$ signaling circuit by interrupting its non-I $\kappa \mathrm{B} \alpha /$ $\mathrm{NF}-\kappa \mathrm{B}(\mathrm{p} 65)$ components would be a highly efficient way for the treatment of recurrent and therapy-resistant prostate cancer, which will avoid the side effects related to indiscriminate IKK/NF- $\kappa \mathrm{B}$ inhibition in normal cells.

The constitutive NF- $\kappa \mathrm{B}$ signaling circuit controls the expression of a group of stem cell transcription factors, including Twist2, Sox2, Oct4, and Nanog, that drives the

\section{Traditional NF-kB activation pathways}

Immune/inflammatory stimuli

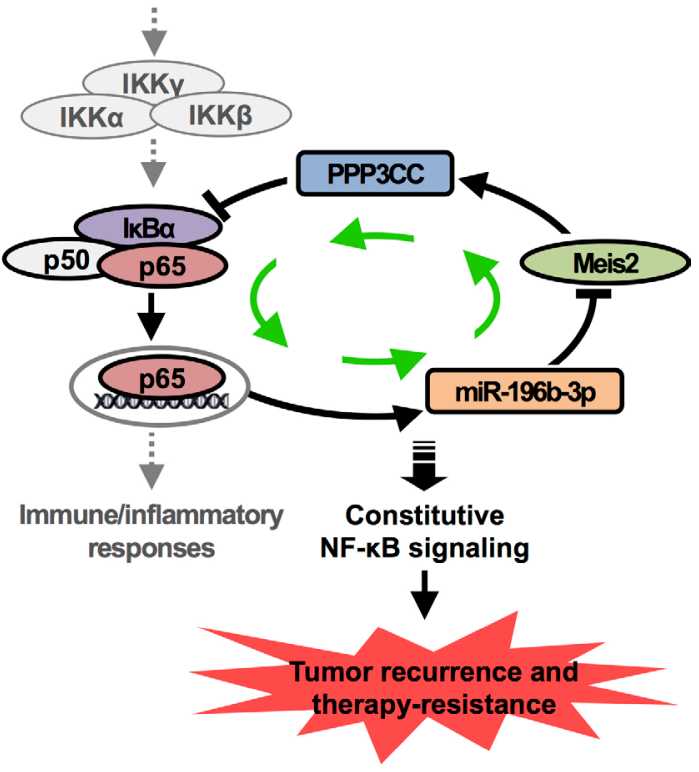

Figure 1: Diagram of constitutively activated NF-кB signaling circuit in recurrent or therapy-resistant prostate tumor. Constitutively activated NF- $\mathrm{BB}$ signaling, maintained by a feed-forward circuit in castration-resistant prostate cancer, is not dependent on traditional IKK $\beta / \mathrm{NF}-\kappa \mathrm{B}$ pathways. 
proliferation and self-renewal of cancer stem cells, leading to tumor recurrence and cancer therapy-resistance [5]. Although these stem cell transcription factors may not be the downstream targets of the individual non-IкB $\alpha / \mathrm{NF}$ $\kappa \mathrm{B}(\mathrm{p} 65)$ components of the circuit, disrupting this circuit by targeting any of the non- $\mathrm{I} \kappa \mathrm{B} \alpha / \mathrm{NF}-\kappa \mathrm{B}(\mathrm{p} 65)$ individual components blocks the expression of these transcription factors and significantly impairs castration-resistant prostate cancer (CRPC) development [5]. Therefore, disrupting this constitutive $\mathrm{NF}-\kappa \mathrm{B}$ signaling circuit by targeting any of its individual non- $\mathrm{I} \kappa \mathrm{B} \alpha / \mathrm{NF}-\kappa \mathrm{B}(\mathrm{p} 65)$ components would be as powerful as direct inhibition of $\mathrm{NF}-\kappa \mathrm{B}$ for the treatment of CRPC.

The non-I $\kappa \mathrm{B} \alpha / \mathrm{NF}-\kappa \mathrm{B}(\mathrm{p} 65)$ components in constitutive NF- $\kappa$ B signaling circuit include miR-196b3p, Meis2, and PPP3CC (Protein Phosphatase 3, Catalytic Subunit, Gamma Isozyme). Further studies are needed to distinguish the best suitable one among these three non$\mathrm{I} \kappa \mathrm{B} \alpha / \mathrm{NF}-\kappa \mathrm{B}(\mathrm{p} 65)$ components for targeting constitutive $\mathrm{NF}-\kappa \mathrm{B}$ signaling in tumor cells. It should be mentioned that the phenomenon and the role of constitutive NF- $\kappa \mathrm{B}$ signaling in tumor recurrence and therapy-resistance were found in CRPC cells, further studies are needed to define if the constitutive NF- $\kappa \mathrm{B}$ signaling circuit also exists in other types of recurrent and therapy-resistant cancer cells. We predict that the constitutive $\mathrm{NF}-\kappa \mathrm{B}$ signaling may be a common phenomenon in most recurrent and therapyresistant cancer cells, however, the components of the constitutive NF- $\mathrm{KB}$ signaling may be different in different types of tumors, as evidenced in our previous studies on breast cancer [7].
Jun-Li Luo: Department of Molecular Medicine, The Scripps Research Institute, Jupiter, FL, USA

Correspondence to: Jun-Li LUo, email jlluo@scripps.edu

Keywords: constitutive NF-KB; prostate cancer; tumor recurrence; therapy-resistance; constitutive signaling circuit

Received: September 19, 2017

Published: October 25, 2017

\section{REFERENCES}

1. Luo JL, et al. J Clin Invest. 2005; 115:2625-32.

2. Perkins ND, et al. Nat Rev Cancer. 2012; 12:121-32. http://dx.doi.org/10.1038/nrc3204M3.

3. Li ZW, et al. J Exp Med. 1999; 189:1839-45.

4. Senftleben U, et al. Science. 2001; 293:1495-9.

5. Jeong JH, et al. Mol Cell. 2017; 65:154-67. http://dx.doi.org/10.1016/j.molcel.2016.11.034.

6. Ammirante $\mathrm{M}$, et al. Nature. 2010; 464:302-5. http://dx.doi.org/10.1038/nature08782M3.

7. Rokavec M, et al. Mol Cell. 2012; 45:777-89. http://dx.doi.org/10.1016/j.molcel.2012.01.015.

Copyright: Jeong et al. This is an open-access article distributed under the terms of the Creative Commons Attribution License 3.0 (CC BY 3.0), which permits unrestricted use, distribution, and reproduction in any medium, provided the original author and source are credited. 